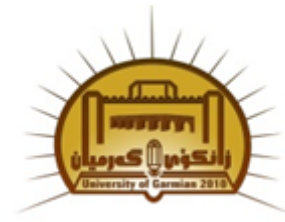

Available online at http://jgu.garmian.edu.krd

Journal of Uni versity of Garmian

https://doi.org/10.24271/garmian.1964022

\title{
Using Dr. Jose Bowen's “Teaching Naked Approach" as a Flipped Instruction Model in EFL College Classes at University of Garmian
}

\author{
Hemn Adil Karim \\ Department of English, College of Education, University of Garmian
}

\section{Article Info}

Received: October, 2019

Revised:Novemeber,2019

Accepted: Novemeber,2019

\section{Keywords}

Teaching Naked Model, Flipped Classroom, teaching technologies, outside classroom, EFL

Corresponding Author

hemn.adil@garmian.edu.krd

\begin{abstract}
The present study aims introducing and proposing the notion and implementation of a flipped classroom model "Teaching Naked" in EFL college classes at university level and proposes some pedagogical suggestions and recommendations. The term coined by Dr. Jose Bowen, which means stripping teaching technologies outside of physical class meetings, instead choosing to use the scheduled time for more discussion-oriented teaching and learning activities (i.e. flipping the classroom, moving the lectures out and moving interaction and problem-solving in ). The study will discuss the role of "Teaching Naked" approach as a flipped instruction model in improving the way of teaching, assessment, and learning among English as a Foreign Language learners. It also deals with the benefits of and barriers to implementing the approach in both teaching and learning processes. The study adds that the approach implementation can be evolutionary.
\end{abstract}

\section{INTRODUCTION}

\subsection{An Overview of the Study}

Students always prefer to gain experience from classroom activities and be involved with activities in order not to have passive learning opportunities when the classroom interaction is limited and receive information from teacher. Students also expect to have more exposure to materials so as to understand the concepts fully; this can be done through involving them with materials outside of the classroom and being engaged with activities inside the classroom. Thus, Teaching Naked Approach provides an environment in which students will be exposed to materials before coming to class when teachers use technology to deliver instructional materials online or offline as pre-class assignment and let students use the class time properly. Consequently, pre-class preparation leads students to be responsible of their own learning. Thus, TN Approach works on how to have students prepare themselves prior to class and work inside the classroom interactively. It also changes the mode of delivery using technology as a tool. To put it another way, in such an approach, students are expected to be involved actively with subjects before coming to class and during the class meeting, which means that it provides opportunity to 
help students engage actively with the course materials and/or content.

In addition, in such flipped classes students can login to their virtual classes such as Google classroom to watch video lectures or read materials that provide information before entering the class. Besides, EFL teachers can provide their students with the opportunity to study where, when, and with whom they like in a guided environment. This guide, of course, can come from teacher as a facilitator and observer or from peers to learn from each other working collaboratively.

Moreover, despite the abilities students own and obtain from the courses, they often become frustrated when using the target language in interactions and putting the knowledge into practice. The courses have not prepared them for the situations, in which language is used; because of either not having knowledge, feeling shy, or not being able to interact easily. This is not to imply that teaching naked approach is superior to the existing one or so called (traditional one). It is simply to acknowledge that different pedagogical methods require different approaches, skills, strategies, and different teaching and learning methods to design courses accordingly. As it is obvious most of the students come from different educational and learning backgrounds, and most of them don't know what learning by doing and collaborative work are, so they think class is a place to receive information from the teacher, to prepare for exam not for the classroom activities, and to memorize the lectures to pass university stages without being involved in learning actively, practically and critically.

\subsection{The Significance of the Study}

To begin with, little or no published research has focused on this area. Besides, newly accepted college students majoring English are in an urgent need to be introduced to the model, and also the courses and programs are required to be designed according to the students' needs and be relevant to meet the demand of the market labor force. So this pedagogical model is more suitable and better for students who study English and need more input, preparation, cooperative work, and interaction, and consequently more necessary contents will be covered accordingly (i.e. it is to increase students' ability in achieving better results and having more learning outcomes). On the other hand, teachers need to complete more content as facilitators while students will be selfdirected, self-regulated, and classes will be more learner-centered.

Furthermore, the study is to focus on;

1. How teaching naked supports English teachers and students and learning objectives in EFL classes at university levels.

2. How teaching naked approach helps instructors and learners in modern ways of learning and teaching using course materials, structure their time, and more effectively drive results.

3. How inverting/flipping the classroom using Teaching Naked approach improves the traditional English teaching and learning.

4. What influence teaching naked approach has on student engagement, preparation for classroom activities, assessment, and completing program contents, and

5. The applicability of the approach in EFL college classes.

\section{Literature Review}

\subsection{Introduction}

Using technology is an inseparable and essential part of education and language teaching. Its use increases in language classes especially language teachers try to make their lessons more productive, attractive, and informative. Incorporating technology into teaching and learning processes has been emerged for decades. Recently some researchers show that how using technology inside and outside the physical classroom has a great impact on teaching and learning English as a second/foreign language, in spite of the difficulties and barriers to it. Using teaching technologies outside the classroom is similar to what the philosophy of blended learning offers. Neumeier (2005) describes blended learning as "a combination of face-to-face and computer assisted learning in a single teaching and learning environment" (164). A group of scholars (Stracke 2007; Dudeney \& Hockly 2007; and Sharma \& Barret 2007) also define it as a combination of face-to-face classroom meeting and an appropriate use of technology in course delivery, the term technology includes recent teaching technologies, such as the Internet, online elements, and the digital elements done offline with a CDROM. In addition, (Tomlinson and Whittaker 2013) define blended language learning as "a particular learning and teaching environment, that combines 
face-to-face and computer assisted language learning; in this instance, the "blend" consisted of learners' independent self-study phases at a computer, with a CD-ROM, and traditional face-to-face classroom learning" (13). Thus, in essence the idea of teaching naked approach is similar to the idea of flipped instruction model and blended learning which is not a new approach, but the term has recently introduced to the teaching world.

The main reason for implementing teaching naked approach and moving technological devices out of the classroom to flip the instructional methods was the main difficulty teachers experience delivering lessons and the time they spent on lecturing and incorporating technological means. As Fink (2003: 130) postulates that most faculty want to teach students to "master the content of the course and to learn how to use that content in some way". Most of us wish to we had more time to spend on the latter; however, class time gets taken up with the former, and higher-order processing of the content gets sacrificed. So the study explores how it would be moving teaching technologies out of the classroom to invert the traditional model and brining live interactions and naked "non-technological" and faceto-face interactions in (i.e. rethinking the use of technological devices and the internet sources in teaching to guide, facilitate, observe, and assess students).

In general, technology in language teaching has been used for decades, but with different forms. If someone has a look at the history of technology from its starting to now, he or she can see that there are many technological devices that have been and are still used both by teachers and students in different ways, at different times, and in different settings either inside or outside the classroom. Their usage has a great effect on the development of teaching and learning that takes on numerous roles such as role of resources, delivery system and productivity.

2.2 Teaching Naked Approach: Definitions and Ideas

The idea comes into existence when in 2009 Jose Antonio Bowen stripped all teaching technologies outside of his physical class meetings, instead choosing to use the scheduled time for more discussion-oriented teaching and learning activities. Just about three years later, he published a book on his model; entitled (Teaching Naked: How Moving Technology out of Your College Classroom will
Improve Student Learning) that suggests using technology outside the classroom as a powerful way to increase naked, non-technological face-to-face interaction with students in the classroom. In other words, he believes using technology this way can force students to engage with course works and give them exposure to course content outside the classroom, and thereby expand the time and quality of interaction and discussion in class. Bowen (2012) further asserts:

At the heart of Teaching Naked is the seeming paradox that technology can be harnessed to enhance the widely desired goals of increased student engagement and faculty-student interaction but that it is most powerfully used outside of class as a way to increase naked, non-technological interaction with students inside the classroom (10).

Teaching naked as a flipped instruction model not only assists students and teachers to connect with each other, but also is a way to help them to cover the content actively and make students continue studying outside the traditional clas room meeting time. It also provides students with enough time to interact with each other, put their interaction into practice, and be prepared for discussions, debates, problem solving, doing their homework during the class meeting time, and both giving and receiving feedback. Thus, students are encouraged to involve more with materials beyond the physical classroom where they are probably passive recipients who take notes and read the notes before the exam without or with a little practice. In other words, the approach can be called "extended classroom" which allows learners to engage in assigned materials beyond the regular class period (Motteram, 2013: 7).

It is also a way of using technology such as surfing the net, looking at videos, listening to podcasts which (Dudeney \& Hockly, 2007) describe as "a method of publishing usually audio files on the internet. A user can subscribe to these files - often at no cost, and download them to his/her computer and a portable listening device such as an MP3 player" (185). Consequently students can have first contact with material before coming to class instead, and use class time for asking and talking about topics, having debate with classmates, and even challenge the teacher in a face-to-face 'naked' interaction. As Bird (2013: 2) describes it as "new ways of using technology, especially ways to move technology 
outside the class, to engage students more fully, and to free class time for deeper learning."

Furthermore, the concept is to remove teaching technologies inside the classroom and replace today's teaching model at university level - one-way lecturing. The strategy further challenges students to use technology on their own - at home, in a library, or some other Wi-Fi location — so that valuable classroom time is spent on face-to-face discussion.

According to Litwin (2012: 1) teaching naked supports the approach and gives some viewpoints such as "Not only does this approach help to better understand the topic; it also forces students to speak (rather than text)". Besides, (ibid. 1) "It helps improving oral communication skills, along with thinking and research skills, and they are also expected to show up well-prepared for discussion with attribution. In addition to that, Young (2009) believes that more than anything else, the present approach wants to discourage professors from using PowerPoint, because they often lean on the slidedisplay program as a crutch rather using it as a creative tool. The approach also reserves lectures for discussion and debate, as nowadays students can get information on the websites that their teacher recommend. This self-discovery activities aid students to remember after graduation as they went through a number of challenges in college days (para. 2).

On the approach, Kate (2012) also declares that Bowen ultimately advocates engaging students during the scheduled face-to-face class meeting in discussions. Not advocating that teachers remove technology from the course altogether, but rather, remove them from the face-to-face contact. Further, Trube (2014, para. 1) states that "Bowen contends that the onslaught of technological resources that in the minds of many jeopardize traditional higher education can in fact enhance the basic thing professors and teachers do in the classroom-advance student learning."

Moreover, Litwin (2010) describes 'Teaching naked' as an innovative and legitimate, but far from new, teaching philosophy. It's a look at the recent past - a throwback. It means reducing the number of lectures and "forcing" students to participate in intellectual conversation about the day's topic (1). In addition, Bird (2013: 2) states that instead of lecture, Bowen advocates active learning for classroom engagement.
The pedagogies for active learning he covers are class writing and discussion, role-playing, lab work, and collaborative, cooperative, and problem-based learning.

Concerning how having students study on their own outside of class time, teachers must do more than simply posting readings, lectures or podcasts online. Instead, students need to interact with materials through posting online quizzes and interactive online assignments in order to be prepared in advance for class activities. Doing so, teachers need to make online communities for groups of students and share a post before every class, send emails, write blogs and ask them to write reflections, also make them respond to other student reflections online and assist them during their arguments.

Trube (2014, para. 2) in Emerging Scholars Blog writes about Bowen's suggestion on how teachers can employ all the technologies outside the classroom, including Power Points, online lectures, podcasts, emails, Facebook Posts, tweets and (CMS) course management systems to promote "outside-theclassroom learning" so that interactive and actionbased learning in the classroom can take the lecture, which is often described as the transfer of information from the notes of the teacher to the notes of the student without engaging the minds of either.

The ideas from teaching naked are many; Bowen believes that learning can be improved by offering more choices for pre-class exposure including reading, listening to an audio or a video podcast, or doing an activity to improve class preparation, collaborative work, and more engagement, since traditionally, students can have the first exposure to new course material during a class period. Then, they complete homework, usually without the aid of the teacher. Besides, teaching naked supports different learning styles, and aligns well with using a variety of technological tools. As Bowen thinks that these various new technologies such as (Khan Academy, Twitter, Facebook, E-mail, Open Courseware, Merlot, YouTube, iTunesU, Google, and Web 2.0 tools like Google Docs, Podcasts, Digital Libraries, Wikis, Slideshare, etc.) will give students more choices; if one explanation does not work, there are many others to try. Those who prefer a chart can use that while others can memorize songs or listen to a lecture. 
Another idea is that Bowen (2012) emphasizes the necessity of making the classroom a stimulating learning environment stating that:

The naked classroom allows us the time to focus on creating significant learning experiences for our students. Delivering content in advance, motivating learning with multiple channels of communication, and constructing assignments that force students to prepare for class will change both your expectations and those of your students for what happens in class. Presenting interactive lectures only when it truly serves your learning outcomes, using active learning techniques, structuring focused discussions, and using technology as a deliberate tool when necessary can turn even the largest survey into an engaging studio environment (213).

All in all, what Bowen proposes is that educators must put more focus on students' learning not technology, since technology is a tool not an instructional and educational technology. The idea of TN also puts more responsibility on the student to be prepared. This will mean a change in learning culture for many students, since some students prepare themselves always, while most of them enter the class unprepared, so it is useful for them all. It also increases the amount of time teachers can interact personally with their students.

\subsection{Teaching Naked Implementation at University} Classes

Regarding the approach's implementation, Bowen (2012) states that "The advantages of a new technology are often hardest to see if you are surrounded by a previous technology that works" (10).

In addition, Bowen (2012) proposes how to use the present approach;

1. Changing course delivery through accessible media using technological tools such as (social media, Google Docs, YouTube, blogs) where students have access out of class. Doing so, students can choose the most suitable way and time to study and practice before coming to class so as to be prepared well to have the class meeting time for discussions and participation (104).

2. How to get students to be engaged with course materials before meeting them in class and freeing up class time using technology or e- communication (email, social media, Skype, YouTube, virtual classrooms, etc.), especially when students refuse to do what they are required to do before coming to class (130).

3. Another idea is using e-communication to free up class time by giving instructions electronically; introducing readings through email; providing links to YouTube videos that students watch before class; and making podcasts/vodcasts. This is to be used in order not to spend ten or twenty minutes of class time to introduce and explain paper assignments (105).

Furthermore, the premises of the approach are presented by Bowen (2012) as follow; firstly, the approach attempts to explain how effective it is when instructors participate actively in the design of class pedagogy applying action-based learning instead of traditional approach. Secondly, social networking offers faculty the chance to change how much and how often students think about course content outside the class. Social networks are a chance to create communities, connect with students, integrate ideas, apply knowledge, influence student culture, and improve student learning (30). Thirdly, teaching naked ideas align with the principles of process education, for instance, Bowen (75) suggests that learning should be like good video games which are challenging, long, hard, and complicated, and they engage the player in active learning. He thinks good games lower the consequences of failure and encourage risk-taking and failures can immediately be used against a new challenge (i.e. he proposes that courses should be developed as video games where students only progress to higher levels of knowledge as they master the lower levels). Finally, teaching naked approach suggests that technology can also be used for assessment, for instance, a multiple-choice test like a survey before every class is a simple but effective way to encourage better engagement and preparation before class (153).

\subsection{The Benefits of and Barriers to Teaching Naked Implementation}

According to Bowen (2012: 113-114) the future of class time is not lecturing. A podcast can be better than a lecture because;

(a) Multiple explanations and multiple modes of accessing the material can be included, 
(b) Time is no longer an issue,

(c) Teachers can talk for longer than they ever could in class and include all of the examples they want (students can skip or rewind), and

(d) Teachers can simultaneously make available separate lectures with all of those alternative ways of introducing the material instead of having to pick just one.

Since they are recyclable, it is also worth the investment of time to create better lectures than the ones you could deliver in person.

In addition, course management systems can easily track the online activity of hundreds or thousands of students at once. Before we enter the classroom, we can now know that students watched the video, listened to the podcast, responded to your email, posted a blog entry, solved all ten of the problems you assigned, reached level five on your video game, sent text messages to their discussion groups, or correctly answered only two questions on the quiz. Faculty can now determine some level of engagement and familiarity with the content before we arrive for class.

Using new technology to increase student engagement outside of the classroom will allow us to spend more time in small groups with students. Instead of over-preparing or rushing through content before the end of the hour, there will now face classes of prepared students. As students listen to podcasts, watch videos, read material, and engage in online activities and get interactive hours inside the classroom, which could make better teachers and improve the quality of student learning.

The interaction can be group discussions, critique on papers in class, work on problems, papers or projects together, teaching peers, and create learning materials for classmates.

Despite easing the process of teaching and learning, there might be some difficulties or the obstacles of implementing the approach; chief among them having a high speed internet access, and it so necessary to get students, teachers, program developers, and administrators buy-in very early in the process. For instance, teachers have to be prepared for the usual technological challenges, for the additional time commitment, for increasing student involvement in the class, and being ready for online office hours to listen to students and answer their questions. This could be highly likely correct for students as well.

Furthermore, (Margulieux, Majerich, \& McCracken, 2013: 5) flipping the classes using teaching naked approach can lead to some other challenges:

1. Students don't show up for class: flipping classroom can have both positive and negative effects on attendance; for instance, students feel that in class meeting time is more engaging so they attend the class. While some students possibly feel there's no need to come to class when the lecture are already accessible online or on CD-ROMs or any other teaching technology tools.

2. In-class and out-of-class works are probably difficult to be relevant and connected.

3. Teachers have to design and prepare activities that are relevant to outside the class lectures

4. Students are as signed with too much work: students may complain about doubling the amount of out-ofclass work, so teachers have to plan accordingly so as not to affect students' workload. To avoid this, the in-class time is geared to answer students' questions, provide feedback on their work, holding discussions on the topics need more time, etc.

5. Students may face difficulty having access to online materials: if students don't have access to materials, teachers can guide them to use university libraries and internet centers, internet cafes and so on where they have access to course materials.

6. It needs time and effort to prepare for in-class activities

7. Some students possibly cannot complete out-ofclass assignments: have students write their reflection on the topic online before each session to check whether they comprehend the lecture videos and podcasts in a way to be sure of what students have done outside of the class.

8. There is no flipped formula (model) that works for every clas sroom.

\section{Flipped Classroom: Historical Background and Definitions}

Baker in the late 1990s coined the term "classroom flip", similarly Lage, Piatt, and Treglia in (2000) introduced "inverted instruction", and regarded as the pioneers of using Flipped Learning, in 2007, Jonathan Bergmann and Aaron Sams began to use live video recordings and screencasting software to record lectures, demonstrations, and slide 
presentations with annotations, then posted on YouTube for students to download and access whenever and wherever it was convenient, as a strategy of presenting course content and providing opportunities for active learning during class time.

Bergmann and Sams (2012) describe Flipped Classroom Model (also referred to as Inverted Classroom) simply as what is traditionally done in class is now done at home, and that what is traditionally done as homework is now completed in class, since class meeting time is rather important than recorded materials that students receive, as it can be used for active learning where students are more responsible for their own learning especially participating in class discussions and in group or pair work, and being engaged with materials. It also gives teachers time and the role of being facilitators and observers explaining what students do not understand and what they have questions about, and working on hands-on activities after sending or giving the materials to students, of course, this can be done easily due to the rapid developments in technology to flip the traditional lectures (Whitley-Grassi \& Baizer, 2010).

Furthermore, (Basal, 2012: 9) states that "the term flipped classroom is commonly used for any classes in which videos are used as pre-prepared lessons. However, the magic in flipped classroom is not just the pre-recorded videos but the free class-time and integration of both by adopting an overall approach". Further, Nicolosi (2012) conducted a research on flipping grammar lessons used "screen cast-o-matic" a free online teaching tool to record lectures which has useful features including (fifteen-minutes recording, shared account and a playlist, microphone from the same recording page, a camera and an editable page that allows users to correct mistakes while recording, and there is no need to be downloaded on computer); found that "the model is not just watching videos at home and brining homework to the classroom, it involves a sustain change of mentality not only in the way of delivering information but also in the students' learning process" (13).

Furthermore, this inverted approach increased from the past decade because of the fast growth of learning technologies and course requirements. So variety of technological devices can help the underlying idea of flipped classroom, which is "instruction should not be limited to class-time, it can take place outside the classroom as well by using different mediums that are not just the pre-recorded lecture videos" (Basal, 2012: 9). This helps instructors planning, selecting, and integrating appropriate engaging activities to fit both inside and outside the classroom environment. To do this, teachers need to utilize different technological tools such as an open source LMS or CMS (e.g. Moodle), Google Classroom, or a "PLN/E - Personal Learning Network/Environment" (Downes, 2007) cited in (Stanley, 2013: 46), or have a professional page or account on 'Facebook, Twitter, LinkedIn, or Google+' as an online community to gather students together; they further need to watch videos, listen to recordings, and read the assigned materials on a timely basis, which they need to have access to a connected device such as a computer, tablet, or smartphone, as Strayer (2007) claims that "extensive use of educational technology to deliver course content outside of class and active learning during class time are central and necessary features of the classroom flip idea" (15).

A number of scholars (Bergmann, Overmeyer, \& Willie 2011; Stone 2012; Engin, 2014) reported the advantages of flipping the classroom for using technology outside the classroom to aid studying and using class time for engagement such as developing life-long learning, involving more with course materials, increasing teacher-student and studentstudent interaction, and classes becoming places of active learning, which promotes students' second language learning, as (Staker and Horn, 2012) believe that flipped classroom is part of a blended learning model in which students have some control over 'time, place, path, and pace' and are involved in active learning. Besides, using technology outside the classroom flipping the instruction structure is to teach students the content before class via recorded materials and readings, and have them complete outof-class work to be prepared and engaged fully in inclass meetings to "attain deeper knowledge in class via activities" (Margulieux, Majerich, \& McCracken 2013: 3).

Flipping the classroom using Teaching Naked Approach may worry teachers regarding student presence in class, especially they believe that if all the content is online or given to students already, they will no longer attend class, Strayer (2007) conducted a research comparing the classroom flip 
and the traditional lecture/homework structure in college level classrooms, found that students are more settled and satisfied with flipped classroom and more comfortable with learning activities. In her study Stone (2012) also found that flipping the class did not have a negative impact on attendance and helped students to be more interested being in the class. Whereas, Stone (2012) reports that flipped teaching strategy has some challenges, it requires more work and careful planning, it requires teacher to be prepared for lecture and structure some of the students' out-of-class study time. In addition, resistance from some students especially resisting what they perceive as extra work.

Gardner (2012: 1-2) also believes although the method helps students ask questions and have opportunity to be engaged which are key elements to learning, the method has its challenges such as creating video lectures is time consuming and students need to have access to what teachers send to them. To overcome these challenges it is better to be open with students, inform them about flipping the course from the very beginning of the course, and show them the outcome of what they have gained and what they will. Han (2015) also explored the effectiveness of flipped classroom in English language teaching and how this model provides a platform for successful language learning and developing learner autonomy. The findings show a positive impact of the model on learner autonomy among ESL students in a summer intensive course for adult international learners in the USA in 2013.

In essence, (Brame, 2013) believes that flipping the classroom means that students gain first exposure to new material outside of class, usually via reading or lecture videos, and then use class time to do the harder work of as similating that knowledge, perhaps through problem-solving, discussion, or debates. In other words, he identifies four key elements of the flipped classroom as it provides an opportunity for students to gain first exposure to content prior to class, an incentive for students to prepare for class, in-class activities that focus on higher-level cognitive activities, and a mechanism to assess student understanding. In addition (Lemmer, 2013) states "this pedagogical model replaces the traditional inclass lecture format with pre-delivered instructional materials and in-class learning activities, and provides students with the opportunity to work in teams and apply knowledge in a directed and guided environment" (463).

Moreover, (Lemmer, 2013) notes that the flipped classroom offers a number of benefits for students and teachers. For instance, Students no longer have to try to capture what the teacher is saying in their handwritten lecture notes. Instead, they can review lecture material at their convenience, stopping and rewinding to fully understand new ideas or skipping forward past information they've already learned. At the same time, instructors spend more time interacting directly with students, instead of lecturing, which provides rapport between them and instant feedback on the way of working, what works properly and what needs more attention (489).

Marshall (2014: 1) also claims that "flipped learning for adult ESL classrooms increases student comprehension of the instructor and the material, interaction among students and with the instructor, and critical thinking skills as a natural part of the learning process.

Further, Hamdan et al. (2013) believe that:

In (some) flipped classrooms the use of videos or other digital technologies to deliver content outside of class does not guarantee that anything different will occur during class time. However, due to the emphasis on students becoming the agents of their own learning rather than the object of instruction, the Flipped Learning model can enable educators to make the shift from teacher-driven instruction to student-centered learning (4).

In a study Snowden (2012) tries to explore teacher perceptions of the use of flipped classroom. The findings reveal that teachers' perceptions are more positive regarding its use as a main method of content delivery, and increasing student-teacher interaction and student responsibility for the content, while some negative responses noted including accountability for students watching the lectures, the need for instance feedback mechanism, and the time it takes to prepare for the method especially in the beginning.

Bergmann and Sams (2012) believe that with flipped classroom students interact more in class, time could be used more flexibly, students who are behind receive more individual attention while advanced students continue to progress.

Hamden et al. (2013) reported that English language learners benefited from flipped classroom in several ways. Besides, (Marshall \& DeCapua, 2013) with 
flipped language lessons the teacher and students could focus on working with the language and practicing it and they note that the organization of the in-class time increases opportunities for interaction and speaking. Further, Nicolosi (2012: 16) declares that although teachers may believe their content, once created, will last for many years, the 'flipped classroom' is successful only when resources are updated with the need of students in mind. The flipped classroom method must be evaluated as an extra educational opportunity available and not as the opportunity to avoid lecturing grammar in class .

All in all, flipping classes is that starts with students think, ask, have questions, explore and facilitated by teacher content, guide, and observation. The teachers mostly create short and tailored videos to help learners not to face misconceptions and explaining topics. Teachers who implement this approach must know that technology is used for the sake of pedagogy and learning process not using technology for the sake of technology. The approach helps learners with more hands-on and interactive works and being monitor and evaluator on their own and each other's learning progress.

\section{CONCLUSIONS}

From the points shown and discussed, some main concluding points can be drawn;

1. Teaching naked is a way using technology outside the classroom to deliver and invert the content, in which students are expected to review materials that would normally be presented in class, including the lectures, outside of class time. Consequently, class time will be freed up to concentrate more on classroom discussion, group work, and being engaged with activities that are normally done outside the classroom, since teachers record short lectures for learners in advance, which replaces the traditional lecture. Meanwhile, learners are expected to view the lecture as a pre-class requirement.

2. Teaching naked as a flipped instruction model provides an effective way of increasing the value of class meeting time, as it encourages practicing and learning out of class. Students in such a model have time and opportunity to experiment with new topics and prepare their thoughts about the as signed course materials before in-class meeting discussions.

3. This model of instruction creates extra work for both students and teachers. However, the more enthusiastic teachers and students are about learning process, the better the students develop their language. So, teachers may find themselves learning a great deal that will ultimately help them to understand their students' needs and assist them accordingly. In such a model, students do the classroom setting task as homework task which leading to classroom presentation, debating, or discussion inside the class room.

4. TN is an opportunity to connect teachers and students actively, in one hand assists students to be engaged studying materials outside the regular class meeting time. In addition, it leads learners to rely on discovery activities in order to become self-reliance and autonomous. On the other hand, it encourages teachers to apply the most updated ways compatible with teaching English in college classes.

5. Flipping instruction can enhance face to face interaction since it allows students to have enough exposure and preparation prior to class discussions.

6. Using the approach to flip classes means to adjust the way of delivery of instruction so as not to let students wait for teachers talk in the class and they silently sit without any interaction or with little interaction, which consequently they will be under a pile of studied materials without being fully involved with, and the only thing they can do is memorizing without understanding or failing to get the knowledge needed.

7. Finally, deepens and maximizes the learning experience of all students because they have enough time to discuss materials and assigned topics.

\section{References}

1. Abdous, M., Camarena, M. M., \& Facer, B. R. (2009). MALL Technology: Use of Academic Podcasting in the Foreign Language Classroom. ReCALL, 21(1). 76-95.

2. Baker, J. W. (2000). The "Classroom Flip": Using web course management tools to become the guide by the side. In J. A. Chambers (Ed.), Selected Papers from the 11th International Conference on College Teaching and Learning (pp. 9-17). Jacksonville, FL: Florida Community College at Jacksonville.

3. Basal, Ahmet (2012). The Use of Flipped Classroom in Foreign Language Teaching. The 3rd Black Sea ELT Conference "Technology: A bridge to Language Learning”. November 15-17. Samsun. 8-12.

4. Bergmann, J., Overmeyer, J., and Willie, B. (2011). The flipped class: What it is and What it is not. The 
Daily Riff. Retrieved from http://www.thedailyriff.com/articles/the-flippedclass-conversation-689.php.

5. Bergmann, J. \& Sams, A. (2012). Flip Your Classroom: Reach Every Student in Every Class Every Day. Washington, DC: International Society for Technology in Education.

6. Bird, J. (2013). Teaching Naked: Part Two. The Weekly Reader, 4(23).Teaching and Learning Center, Winthrop University, Rock Hill, SC. March 18.

7. Bowen, J. A. (2012). Teaching Naked: How Moving Technology Out of Your College Classroom Will Improve Student Learning. San Francisco: JosseyBass.

8. Brame, C. J. (2013). Flipping the Classroom. Vanderbilt University's Center for Teaching. Retrieved from http://cft.vanderbilt.edu/teaching--guides/teaching--activities/flipping---the--classroom/. Access date 24/7/2019.

9. Dudeney, G. \& Hockly, N. (2007). How to... Teach English with Technology. Harlow: Pearson Education Limited.

10. Engin, M. (2014). Extending the flipped classroom model: Developing second language writing skills through student-created digital videos. Journal of the Scholarship of Teaching and Learning, 14(5). 12-26.

11. Fink, L. D. (2003). Creating significant learning experiences: An integrated approach to designing college courses. San Francisco: Jossey-Bass.

12. Gardner, J. G. (2012). The Inverted Agricultural Economics Classroom: A new way to teach? A new way to learn? A Paper Presented in the Agricultural and Applied Economics Association's 2012 AAEA Annual Meeting, Seattle, Washington, August 12-14.

13. Hamdan, N., McKnight, P., McKnight, K., \& Arfstrom, K. M. (2013). A Review of Flipped Learning: Flipped Learning Network.

14. http://www.flippedlearning.org/cms/lib07/VA019231 12/Centricity/Domain/41/LitReview_FlippedLearnin g.pdf

15. Han, Y. J. (2015). Successfully Flipping the ESL Classroom for Learner Autonomy. New York State (NYS) TESOL Journal, 2(1). 98-109.

16. Kate, M. (2012). Teaching Naked: A Review. Technology for Teaching and Learning.

Worcester Polytechnic Institute, October 24. Retrieved from http://wp.wpi.edu/atctt1/2012/10/24/teaching-naked-book-and-workshop-
review/\#.WTXEJJKGPIU. Access date 25/7/2019. 11:51 pm

17. Lage, M. J., Platt, G. J., \& Treglia, M. (2000). Inverting the classroom: A gateway to creating an inclusive learning environment. The Journal of Economic Education,31(1), 30-43.

18. Lemmer, C. A. (2013). A View from the Flip Side: Using the "Inverted Classroom" to Enhance the Legal Information Literacy of the International LL.M. Student. Law Library Journal, 105(4). 461-491.

19. Litwin, L. (2012). Teaching Naked: The Flipped Classroom. National School Public Relations Association. Retrived from http://www.nspra.org/e_network/201208_trendtracker. Access Date 21/7/2019. 3:06 PM

20. Margulieux, L., Majerich, D. \& McCracken, M. (2013) C21U's Guide to Flipping Your Classroom. Georgia Tech Center for 21st Century Universities.

21. Marshall, H. W. (2014). The Flipped Learning Approach in Adult ESL Classrooms. AAACE Annual Conference, Charleston, SC. November 4-7.

22. Marshall, H. W. \& DeCapua, A. (2013). Making the Transition to Classroom Success: Culturally Responsive Teaching for Struggling Language Learners. Michigan: University of Michigan Press.

23. Motteram, G. (2013). Innovations in learning technologies for English language teaching. London: Spring Gardens.

24. Neumeier, P. (2005). A closer look at blended learning - parameters for designing a blended learning environment for language teaching and learning. ReCALL, 17(2). 163-178.

25. Nicolosi, A. (2012). Grammar Lessons with the Flipped Classroom Method. The 3rd Black Sea ELT Conference "Technology: A bridge to Language Learning”. November 15-17. Samsun. 13-17.

26. Sharma, P. \& Barret, B. (2007). Blended Learning. Oxford: Macmillan.

27. Snowden, K. E. (2012). Teacher Perceptions of the Flipped Classroom: Using Video Lectures Online to Replace Traditional In-Class Lectures. University of North Texas. MA Thesis.

28. Staker, H., \& Horn, M. B. (2012). Classifying K-12 Blended Learning. Mountain View, CA: Innosight Institute. Retrieved from; https://www.christens eninstitute.org/wp content/uploads/2013/04/Clas sifying-K-12-blendedlearning.pdf. Date of Access July 21st 2019 
29. Stanley, G. (2013). Integrating Technology into Secondary English Language Teaching. In Motteram, G. (Ed.), Innovations in learning technologies for English language teaching (pp. 43-66). London: Spring Gardens.

30. Stone, B. (2012). Flip Your Classroom to Increase Active Learning and Student Engagement. 28th Annual Conference on Distance Teaching \& Learning. Madis on, University of Wisconsin.

31. http://www.uwex.edu/disted/conference/Resource_lib rary/proceedings/56511_2012.pdf

32. Stracke, E. (2007). A road to understanding: A qualitative study into why learners drop out of a blended language learning (BLL) environment. ReCALL, 19(1). 57-78.

33. Strayer, J. F. (2007). The effects of the class room flip on the learning environment: A comparison of learning activity in a traditional classroom and a flip classroom that used an intelligent tutoring system. Doctoral Dissertation. Retrieved from OhioLINK

34. https://etd.ohiolink.edu/ap:0:0:APPLICATION_PRO CESS=DOWNLOAD_ETD_SUB_DOC_ACCNUM: ::F1501_ID:osu1189523914,attachment
35. Tomlinson, B. \& Whittaker, C. (2013). Blended Learning in English Language Teaching: Course Design and Implementation. London: Spring Gardens.

36. Trube, B. (2014). Book Review: Teaching Naked. Emerging Scholars Blog: InterVarsity's Emerging Scholars Network. Retrieved from http://blog.emergingscholars.org/2014/07/bookreview-teaching-naked/ Access date 24/7/2019

37. Whitley-Grassi, N. \& Baizer, J. S. (2010). Video lecture capture in physiology course: student attendance, video viewing and correlations to course performance. International Journal of Instructional Technology and Distance Learning, 7(10), 31-38.

38. Young, J. R. (2009). When Computers Leave Classrooms, so Does Boredom. Chronicle of Higher Education, 55(42). Retrieved from https://eric.ed.gov/?id=EJ853097. Access date 24/7/2019 